\title{
Neonates Born to Mothers with Graves' Disease: 15 Year Experience of a Pediatric Endocrinology Department
}

\author{
Filhos de Mães com Doença de Graves: Experiência de \\ 15 Anos de uma Unidade de Endocrinologia Pediátrica
}

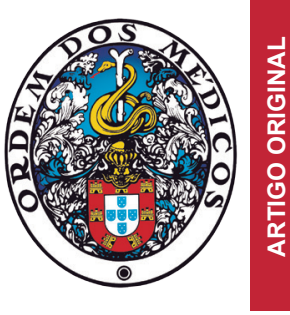

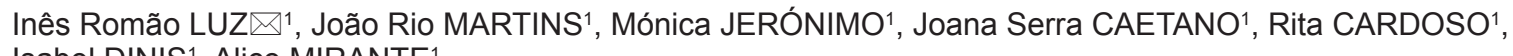
Isabel DINIS ${ }^{1}$, Alice MIRANTE 1

Acta Med Port 2020 Jul-Aug;33(7-8):483-490 - https://doi.org/10.20344/amp.12279

\section{ABSTRACT}

Introduction: Graves disease is characterized by the existence of autoantibodies directed to the thyrotropin receptor, which can have a stimulatory/inhibitory action, in women with the condition, their fetus or neonate. Our aim was to review the case series of these neonates in order to establish neonatal thyroid function predictors.

Material and Methods: Retrospective cohort study of the database of the Department of Pediatric Endocrinology, including patients born to mothers with Graves' disease, between 2002 and 2017. Clinical and biochemical data were collected from mothers and offspring

Results: Fifty newborns, from 46 women with a median of 3.5 years after diagnosis, were included. During all trimesters of pregnancy, more than half of women had positive autoantibodies directed to the thyrotropin receptor. Not every woman had a complete thyroid function evaluation every trimester. In 32 newborns, cord blood screening was done. During the neonatal period, there were three cases of hypothyroidism and two of hyperthyroidism. The mothers of these five newborns had higher levels of free thyroid hormones during the second trimester $(p=0.03)$. The level of antibodies directed to the thyrotropin receptor was significantly higher in the cord blood $(p=0.03)$ and in the first neonatal test $(p=0.03)$ of these dysthyroid newborns.

Discussion: Our results reinforce the need for every pregnant woman with Graves' disease to be subject to thyroid function and autoantibodies evaluation during every trimester, as well as the importance of evaluating these antibodies in cord blood.

Conclusion: High levels of free thyroid hormones during the second trimester of pregnancy and antibodies directed to the thyrotropin receptor value in cord blood are predictors of dysthyroidism in neonates born from women with Grave's disease.

Keywords: Graves Disease; Infant, Newborn; Mothers; Pregnancy Complications; Prenatal Exposure Delayed Effects

\section{RESUMO}

Introdução: A doença de Graves é caraterizada pela existência de autoanticorpos dirigidos ao recetor da tirotrofina, que podem ter uma ação estimuladora/inibitória, ao nível da mulher com a doença, bem como do seu feto ou recém-nascido. Quisemos rever a nossa série de casos de filhos de mães com doença de Graves de forma a estabelecer preditores da função tiroideia neonatal.

Material e Métodos: Estudo retrospetivo de uma coorte da base de dados da Unidade de Endocrinologia Pediátrica, composta por filhos de mães com doença de Graves, seguidos entre 2002 e 2017. Foram recolhidos dados clínicos e laboratoriais dos processos clínicos das progenitoras e seus filhos.

Resultados: Foram incluídos 50 recém-nascidos, de 46 mulheres com uma mediana de 3,5 anos de diagnóstico. Em todos os trimestres de gravidez, mais de metade das mulheres tinham autoanticorpos dirigidos ao recetor da tirotrofina positivos. Nem todas fizeram uma avaliação trimestral completa da função tiroideia. O rastreio no sangue do cordão foi realizado em trinta e dois recémnascidos. Durante o período neonatal houve três casos de hipotiroidismo e dois de hipertiroidismo. As mães destes recém-nascidos tinham valores mais elevados das frações livres das hormonas tiroideias no segundo trimestre $(p=0,03)$. O valor dos anticorpos dirigidos ao recetor da tirotrofina no sangue do cordão e na primeira avaliação neonatal foi significativamente mais elevado $(p=0,03$ em ambos) nos recém-nascidos distiroideus.

Discussão: Os nossos resultados sublinham a importância de todas as mulheres grávidas, com doença de Graves, fazerem a avaliação da função tiroideia e autoanticorpos dirigidos ao recetor da tirotrofina em cada trimestre, bem como da avaliação destes anticorpos no sangue do cordão.

Conclusão: Valores elevados das frações livres das hormonas tiroideias no segundo trimestre de gravidez e de anticorpos dirigidos ao recetor da tirotrofina no sangue do cordão são preditores de distiroidismo nos recém-nascidos filhos de mães com doença de Graves. Palavras-chave: Complicações da Gravidez; Doença de Graves; Efeitos Tardios da Exposição Pré-Natal; Mães; Portugal; RecémNascido

\section{INTRODUCTION}

Graves' disease (GD) is an autoimmune disorder characterized by the existence of autoantibodies directed to the thyrotropin receptor (TSHR) in the thyroid gland. It is the commonest cause of hyperthyroidism in women of reproductive age. ${ }^{1,2}$ The amount of pregnant women with GD is reported to be between $0.1 \%$ and $0.4 \%{ }^{3}$ The importance of this disease to the fetus and neonate lays in the fact that these antibodies - TRAb - are from the IgG class and, therefore, cross the placenta, having a repercussion on the fetal thyroid function from as early as 10 weeks of gestation. ${ }^{4}$ TRAb can have a stimulatory or inhibitory action on the TSHR, thus inducing hyper or hypothyroidism, respectively. ${ }^{1,4}$ When the mother's disease is not controlled, high levels of maternal thyroxin (T4) can induce suppression of

1. Pediatric Endocrinology Unit. Hospital Pediátrico. Centro Hospitalar e Universitário de Coimbra. Coimbra. Portugal.

$\square$ Autor correspondente: Inês Romão Luz. inesluz1988@gmail.com

Recebido: 02 de maio de 2019 - Aceite: 28 de Agosto de 2019 | Copyright @ Ordem dos Médicos 2020 
thyrotropin/thyroid stimulating hormone (TSH) synthesis and, therefore, central hypothyroidism, but also thyroid dysgenesis and thus primary hypothyroidism in the fetus. ${ }^{1,5}$

Besides the effect of the disease itself, maternal medication also have influence on fetal thyroid development and outcomes. ${ }^{5}$ There are three therapeutic options for women with GD: anti-thyroid drugs (ATD) - propylthiouracil and methimazole, radioactive iodine $\left({ }^{131} \mathrm{I}\right)$ and surgery (thyroidectomy). ${ }^{2,5}$ Both propylthiouracil and methimazole have been used in pregnant women with GD, with a preference for propylthiouracil in the first trimester, and for methimazole in the other two, due to the risk of methimazole-induced embryopathy (mainly aplasia cutis, esophageal and choanal atresia). However, the 2017 guidelines of the American Thyroid Association stress the lack of evidence for this switch, as both have adverse effects, and a change of ATD can lead to a period of less-tight control. ${ }^{2}$ The ${ }^{131} \mathrm{I}$ is precluded as a treatment during gestation, and surgery is indicated only for special cases, preferably during the second trimester. ${ }^{2,6}$

For the Pediatrician, there is importance in the fetal and subsequent neonatal outcomes. Fetal hyperthyroidism goes from unnoticed to being the cause of fetal death, but may also comprise goiter, growth restriction, oligohydramnios and prematurity. There is usually a continuum to the extrauterine life, with a transient picture of neonatal hyperthyroidism which can become apparent 2-5 days after birth or, rarely, 1 - 2 weeks after birth. ${ }^{5,7}$ Neonatal hyperthyroidism occurs in $2 \%$ of the offspring of mothers with GD, and although it is usually transitory, it can be life-threatening, with the need for admission to the intensive care unit. ${ }^{8,9} \mathrm{Hy}-$ pothyroidism is usually transitory, and it represents around $2 \%$ of cases of congenital hypothyroidisms. ${ }^{1}$ It is important to remember that ATD pass through the placenta, and, therefore, can delay the presentation of hyperthyroidism, or even induce temporary hypothyroidism. ${ }^{4}$

In Portugal, there is a universal newborn screening program which includes neonatal hypothyroidism. There isn't a national protocol for the evaluation of pregnant women with GD and their offspring, so neonatal hyperthyroidism can be overlooked. ${ }^{10-12}$ Although this entity can be justified by a mutation, as it occurs in the McCune-Albright syndrome, the main cause is the transplacental passage of TRAb from mothers. ${ }^{7}$ In order to fill this gap, the Endocrinology Section of the Portuguese Society of Pediatrics published a guideline this year focusing on the management of these offspring. ${ }^{13}$

In this study our aims were:

- to characterize the disease follow-up throughout pregnancy, namely thyroid function assessment through biochemical determinations and therapeutics in each trimester;

- to determine the rate of neonatal dysthyroidism;

- to evaluate which factors can predict neonatal dysthyroidism.

\section{MATERIAL AND METHODS}

\section{Study design and patients}

We conducted a retrospective cohort study using data from the database of our Department of Pediatric Endocrinology. We included patients referred due to maternal GD, from the beginning of 2002 to the end of 2017. The authors have followed the protocols of their hospital on the publication of data. The data was anonymised and none of the authors had access to patient identification. The study was conducted in accordance with the Helsinki Declaration.

\section{Clinical data}

The following maternal data was collected: number of complete years of mothers' GD diagnosis before pregnancy, history of thyroidectomy (yes/no), number of complete years between thyroidectomy and pregnancy, history of ${ }^{131}$ I therapy before pregnancy (yes/no), number of complete years between ${ }^{131}$ I therapy and pregnancy, and other family history of thyroid disease (yes/no).

Focusing on pregnancy and the newborn, we searched for: obstetric ultrasound anomalies, pregnancy complications, medical treatment of GD in each trimester, birth date, gender, pregnancy order, delivery order, gestational age at birth (complete weeks), weight/height/cephalic perimeter at birth, Apgar score at first/fifth/tenth minutes, breastfeeding during maternity leave (yes/no), neonatal signs of hyperthyroidism and hypothyroidism (yes/no and which), use of medicines for thyroid disease during the neonatal period (which one, when it was started (days of age) and for how long it was administered (complete months), weight evolution during the first clinical meetings at the Pediatric Endocrinology Unit. Somatometry at birth was converted to adjusted Z-scores (concerning complete gestation weeks and gender) using the Excel ${ }^{\circledR}$ sheet Research Bulk Calculator, downloaded from https://www.ucalgary.ca/ fenton/2013chart. Weight evolution at the Pediatric Endocrinology Unit was recorded in grams, and then converted to Z-scores using the AnthroPlus ${ }^{\circledR}$ software, downloaded from http://www.who.int/growthref/tools/en/.

\section{Biochemical data}

Each trimester we searched for levels of TRAb, TSH, free T4 (fT4) and free triiodothyronine (fT3); blood cord TRAb, TSH, fT4 and fT3; each neonatal and subsequent levels of TRAb, TSH, fT4, and fT3 in the offspring.

There are no Portuguese reference ranges for thyroid hormones, TSH or antibodies, neither in adult population nor for the different trimesters of pregnancy, or for the neonatal period. At our center, measurements are made through chemiluminescence, with TRAb being measured with Roche's Cobas analyzer and the other antibodies and hormones with Abbot's ARCHITECT analyzers. Therefore, we searched for reference ranges obtained with the same technique and analyzer. Recently, Adeli $\mathrm{K}$ et al published the results of the CALIPER initiative, with biochemical reference ranges for the pediatric age, where the levels of TSH, fT4 and fT3 using Abbot's ARCHITECT are specified 
by age and gender. ${ }^{15}$ Although the population used in this study was from Canada, its design and techniques make it the best reference available. Regarding female reference ranges during pregnancy, the American Thyroid Association guidelines make reference to different studies made worldwide, with the one by Bocos-Terraz et al being the most similar, ethnically speaking. 2,16 The technique and analyzer are the same; therefore, we used those values as reference. Focusing on TRAb, we considered as reference ranges the ones suggested by the manufacturer (cut-off for positivity of $1.5 \mathrm{U} / \mathrm{L})$. The values considered as reference ranges of thyroid function tests from cord blood were selected from a paper by Mehari A et al; they were determined by the same technique, but with Cobas analyzer. ${ }^{17}$

Mothers and offspring were classified as euthyroid, hypothyroid or hyperthyroid based on TSH values, if they were in, above or under the reference ranges, respectively.

\section{Statistical analysis}

For continuous data we assessed normality through the construction of histograms and using the Shapiro-Wilk test. For normal data we used the descriptive measures mean and standard deviation (SD). All non-normal data are skewed, and for these data we used the median and interquartile range (IQR $=25^{\text {th }}$ and $75^{\text {th }}$ percentiles). In order to compare two binomial categories, we used the chi-square test or the Fisher's exact test for small cell counts. When continuous variables were involved, we used the Wilcoxon rank-sum test. We considered $p<0.05$ for statistical significance. Statistical analysis was performed with Stata $₫ / I C$ 14.2 software.

\section{RESULTS \\ Mothers}

\section{Population characterization}

Between 2002 and 2017, there were 46 women with GD, who gave birth to 50 newborns (two cases of multiple pregnancies and two women were pregnant twice, making it a total of forty-eight pregnancies). Seven women had a family history of thyroid disease (one case of multiple pregnancy). In three cases there were abnormalities in the obstetric ultrasound: two fetuses with growth-restriction and one with thyroid hypertrophy. Regarding time before pregnancy with the diagnosis of Graves' disease, the median was 3.5 years (IQR 1 - 7). Additional data can be found in Table 1.

\section{Treatment}

Only one of the mothers $(2.08 \%)$ had undergone surgery, which occurred one year before pregnancy. With
Table 1 - Description of each pregnancy of mothers with Graves disease $(n=48)$

\begin{tabular}{llc}
\hline Variables $(\mathrm{n})$ & Units & \\
\hline Gestation (48) & & $2(1-2)$ \\
Delivery (48) & & $1(1-2)$ \\
WG (47) & & $38.6(+/-1.3 \mathrm{SD})$ \\
1 $^{\text {st }}$ trimester & & \\
TRAb (22) & $\mathrm{U} / \mathrm{L}$ & $3.5(0-5.5)$ \\
TSH (31) & $\mathrm{mU} / \mathrm{L}$ & $0.094(0.006-2.600)$ \\
fT4 (31) & $\mathrm{ng} / \mathrm{dL}$ & $1.2(1.0-1.9)$ \\
fT3 (18) & $\mathrm{pg} / \mathrm{mL}$ & $3.6(3.2-4.8)$ \\
$2^{\text {nd }}$ trimester & & \\
TRAb (15) & $\mathrm{U} / \mathrm{L}$ & $4.1(2.2-10.2)$ \\
TSH (32) & $\mathrm{mU} / \mathrm{L}$ & $0.938(0.004-2.145)$ \\
fT4 (31) & $\mathrm{ng} / \mathrm{dL}$ & $1.0(0.8-1.2)$ \\
fT3 (20) & $\mathrm{pg} / \mathrm{mL}$ & $3.5(2.6-4.7)$ \\
$3^{\text {rd }}$ trimester & & \\
TRAb (27) & $\mathrm{U} / \mathrm{L}$ & $2.0(0.4-3.8)$ \\
TSH (39) & $\mathrm{mU} / \mathrm{L}$ & $1.500(0.140-2.750)$ \\
fT4 (39) & $\mathrm{ng} / \mathrm{dL}$ & $0.9(0.8-1.0)$ \\
fT3 (23) & $\mathrm{pg} / \mathrm{mL}$ & $2.8(2.5-3.1)$ \\
\hline
\end{tabular}

Some values were under the detection nadir, therefore we considered them as zero. Measures of distribution: mean and standard deviation; median and interquartile range.

fT3: free triiodothyronine; fT4: free thyroxin; TRAb: thyrotropin receptor antibodies; TSH: thyrotropin/thyroid stimulating hormone; WG: weeks of gestation

regards to ${ }^{131}$ I, 16 mothers $(33.33 \%)$ underwent this therapy; the median difference between the treatment and pregnancy was four years $(n=15)$, with one mother doing it with a difference of six-months.

The woman with a history of surgery was prescribed levothyroxine from the beginning until the end of the pregnancy. Of those who underwent therapy with ${ }^{131} \mathrm{I}, 10(62.50 \%)$ had hypothyroidism and required levothyroxine. Five (31.25\%) required ATD during the first trimester, two (12.50\%) during the second trimester and one (6.25\%) during the third trimester. The woman who required ATD throughout pregnancy had undergone ${ }^{131}$ I therapy over three before.

Seven women were not taking medication during pregnancy. The use of each therapy by trimester is represented in Table 2.

\section{Laboratory evaluation}

See Fig. 1.

\section{Offspring}

Population characterization

See Table 3.

\section{Laboratory evaluation}

In 27 cases, TRAb were determined in cord blood, and

Table 2 - Prevalence of each medical therapy by pregnancy trimester (total number of pregnancies 48)

\begin{tabular}{lccc}
\hline & MMI & PTU & LTX \\
\hline $\mathbf{1}^{\text {st }}$ trimester (36) & $10(27.78 \%)$ & $15(41.67 \%)$ & $11(30.56 \%)$ \\
$\mathbf{2}^{\text {nd }}$ trimester (37) & $10(27.03 \%)$ & $13(35.14 \%)$ & $14(37.84 \%)$ \\
$3^{\text {rd }}$ trimester (35) & $9(25.71 \%)$ & $11(31.43 \%)$ & $15(42.86 \%)$ \\
\hline
\end{tabular}

LTX: levothyroxine; MMI: methimazole; PTU: propylthiouracil 


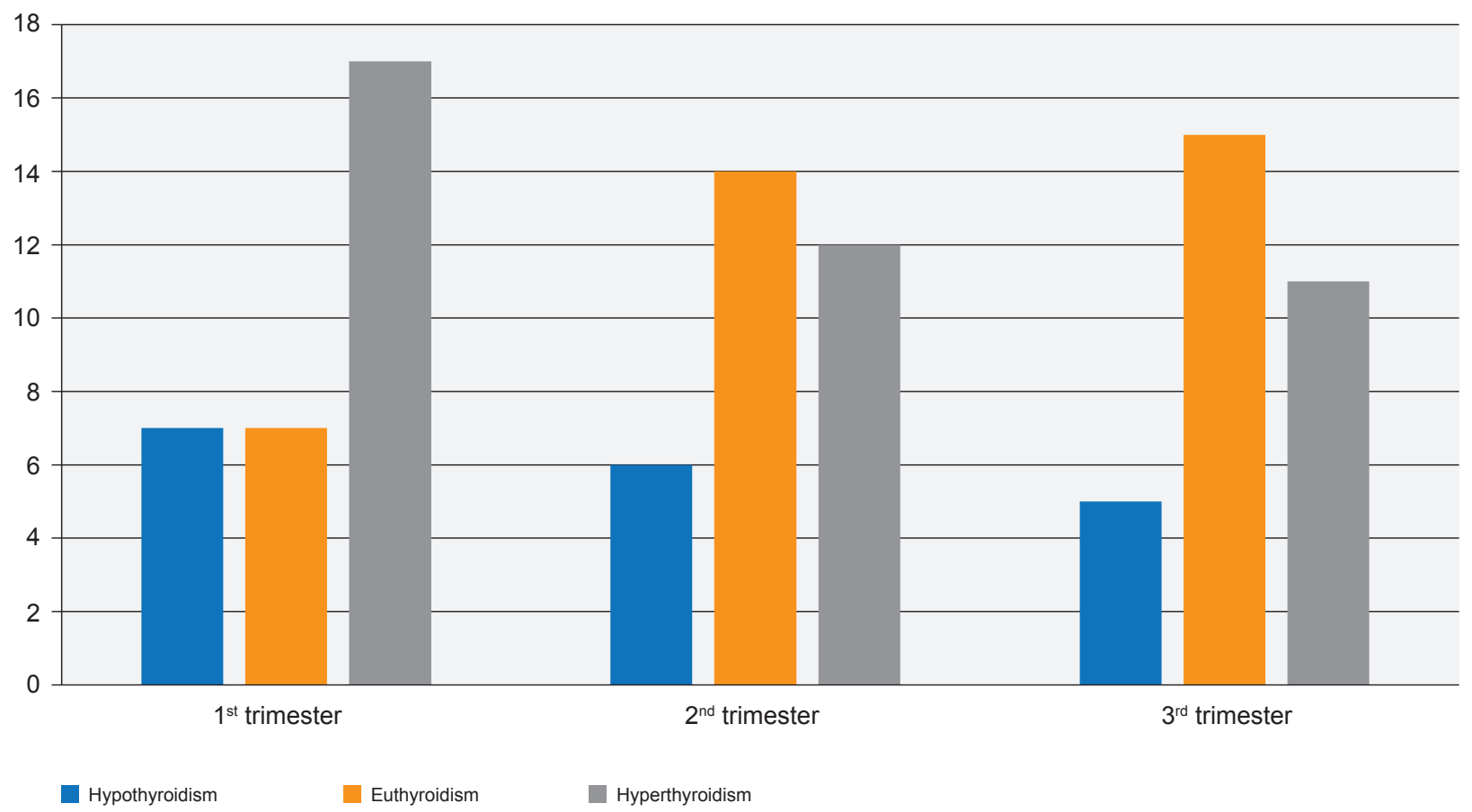

Figure 1 - Thyroid status classification of pregnant women per trimester

were positive in nine (33.30\%). TSH was determined in 32: it was decreased in three $(9.40 \%)$ newborns, within the reference range in $25(78.10 \%)$ and elevated in four $(12.50 \%)$ cases. The median days of life at which the first blood determinations $(n=48)$ were made was four days, with a minimum of one day of life and a maximum of 67 days of life, and the second $(n=35)$ was 18 days (minimum 5 - maximum 366). Considering the levels of the first neonatal blood determinations, there were twelve cases $(25.00 \%)$ of subclinical hypothyroidism, two cases $(4.20 \%)$ of hypothyroidism and five cases (10.40\%) of subclinical hyperthyroidism.

In those with positive TRAb in cord blood, only one had decreased TSH (0.028 $\mathrm{mIU} / \mathrm{L})$, who developed hyperthyroidism; TSH was elevated in five cases, (from 13.7 to 133 $\mathrm{mIU} / \mathrm{L}$ ), with one being diagnosed with congenital hypothyroidism. There was another case of neonatal hyperthyroidism but the cord blood test was not performed. The first laboratorial evaluation was carried out six days after birth, with TSH levels of $0.005 \mathrm{mIU} / \mathrm{L}$ and TRAb levels of $160 \mathrm{U} / \mathrm{L}$.

\section{Treatment and follow-up}

Five newborns $(10.00 \%)$ required therapy, three $(6.00 \%)$ received levothyroxine and two (4.00\%) methimazole plus propranolol. At the maternity hospital, no signs of disease were apparent in all except one newborn with neonatal hyperthyroidism.

Of those who received levothyroxine, the girl with congenital hypothyroidism, now aged 11 years old, maintains therapy. The other two required it for 17 and 36 months, respectively, after which remained euthyroid.

The two newborns with transient hyperthyroidism were admitted in the Intensive Care Unit (ICU) for five and six days, respectively. In the first case, the newborn was admitted when he was 13 days old, after evaluation at the clinic: he had failure to thrive, tachycardia and hypertension, with a TSH level of $0.007 \mathrm{mU} / \mathrm{L}$ and TRAb level $>40 \mathrm{U} / \mathrm{L}$. He was started on methimazole and propranolol in the ICU, with good progress. The second newborn had signs of disease since the first hour of life, with tachycardia and left ventricular concentric hypertrophy. He was transferred to the ICU at 13 days of life, with a TSH level of $0.0006 \mathrm{mU} / \mathrm{L}$, and showed good progress with the introduction of methimazole and propranolol (Table 4).

\section{Association between maternal variables and neonatal outcomes}

The incidence of hyperthyroidism and hypothyroidism in our cohort was $4 \%$ and $6 \%$, respectively. Since we only had two patients with hyperthyroidism we cannot make a comparison with the other offspring in terms of trying to establish predictors.

Newborns with hyperthyroidism born from mothers with a more recent diagnosis had the highest levels of TRAb and the lowest levels of TSH during the first and second trimesters. During the third trimester TRAb levels decreased. In the cord blood, and in the first neonatal determination, this group appeared had the highest levels of TRAb and the lowest levels of TSH again.

During pregnancy, the levels for which we found differences in outcomes were fT4 $(p=0.03)$ and fT3 $(p=0.03)$ during the second trimester, with higher levels for the mothers of newborns with dysthyroidism. We also found a significant difference between TRAb levels in the cord blood between euthyroid and dysthyroid newborns $(p=0.03)$, and 
Table 3 - Different characteristics of the pregnancies and neonatal periods by group: neonates with transitory hyperthyroidism, neonates with hypothyroidism and those who didn't require neonatal therapy.

\begin{tabular}{|c|c|c|c|c|}
\hline & \multirow{2}{*}{ Units } & \multicolumn{2}{|c|}{$\begin{array}{l}\text { Dysthyroid } \\
(n=5)\end{array}$} & \multirow{2}{*}{$\begin{array}{l}\text { Euthyroid } \\
\qquad(n=45)\end{array}$} \\
\hline & & $\begin{array}{l}\text { Hyperthyroidism } \\
\qquad(n=2)\end{array}$ & $\begin{array}{l}\text { Hypothyroidism } \\
\qquad(n=3)\end{array}$ & \\
\hline Gestation & & $1.5(1-2)$ & $3(2-4)$ & $2(1-2)$ \\
\hline Delivery & & $1(1-1)$ & $2(2-3)$ & $1(1-2)$ \\
\hline WG & & $38(37-39)$ & $38(38-39)$ & $39(38-39.5)$ \\
\hline Prematurity & & $0(0 \%)$ & $0(0 \%)$ & $3(6.7 \%)$ \\
\hline US findings & & $1(50 \%)$ & $0(0 \%)$ & $2(4.4 \%)$ \\
\hline Caesarean & & $2(100 \%)$ & $1(33.3 \%)$ & $10(22.7 \%)$ \\
\hline Family history & & $0(0 \%)$ & $1(33.3 \%)$ & $7(15.6 \%)$ \\
\hline Complications & & $2(100 \%)$ & 1 & $9(20.5 \%)$ \\
\hline Years disease & & $0.5(0-1)$ & $6(1-8)$ & $3.5(1-7)$ \\
\hline 131 I & & $1(50 \%)$ & $0(0 \%)$ & $1(33.3 \%)$ \\
\hline Surgery & & $0(0 \%)$ & $0(0 \%)$ & $1(2.2 \%)$ \\
\hline $\begin{array}{l}\mathbf{1}^{\text {st }} \text { trimester } \\
\text { TRAb (22) } \\
\text { TSH (31) } \\
\text { fT4 (31) } \\
\text { fT3 (18) }\end{array}$ & $\begin{array}{l}\mathrm{U} / \mathrm{L} \\
\mathrm{mU} / \mathrm{L} \\
\mathrm{ng} / \mathrm{dL} \\
\mathrm{pg} / \mathrm{mL}\end{array}$ & $\begin{array}{c}29.4(29.4-29.4) \\
0.015(0.150-0.150) \\
2.8(2.8-2.8) \\
15(15-15)\end{array}$ & $\begin{array}{c}3.8(3.8-3.8) \\
0.033(0.033-0.033) \\
1.6(1.6-1.6) \\
3.5(3.5-3.5)\end{array}$ & $\begin{array}{c}2.6(0-4.9) \\
0.112(0.006-2.600) \\
1.1(1.0-1.5) \\
3.6(3.2-4.7)\end{array}$ \\
\hline $\begin{array}{l}2^{\text {nd }} \text { trimester } \\
\text { TRAb (15) } \\
\text { TSH (32) } \\
\text { fT4 (31) } \\
\text { fT3 (20) }\end{array}$ & $\begin{array}{l}\mathrm{U} / \mathrm{L} \\
\mathrm{mU} / \mathrm{L} \\
\mathrm{ng} / \mathrm{dL} \\
\mathrm{pg} / \mathrm{mL}\end{array}$ & $\begin{array}{c}22.6(22.6-22.6) \\
0.004(0.003-0.005) \\
1.9(1.4-2.3) \\
8.5(4.7-12.2)\end{array}$ & $\begin{array}{c}10.2(10.2-10.2) \\
0.635(0-1.270) \\
1.5(1.0-2.0) \\
4.9(3.9-5.8)\end{array}$ & $\begin{array}{c}4.1(2.2-4.6) \\
0.946(0.048-2.200) \\
1(0.8-1.15) \\
3.2(2.5-3.8)\end{array}$ \\
\hline $\begin{array}{l}3^{\text {rd }} \text { trimester } \\
\text { TRAb (27) } \\
\text { TSH (39) } \\
\text { fT4 (39) } \\
\text { fT3 (23) }\end{array}$ & $\begin{array}{l}\mathrm{U} / \mathrm{L} \\
\mathrm{mU} / \mathrm{L} \\
\mathrm{ng} / \mathrm{dL} \\
\mathrm{pg} / \mathrm{mL}\end{array}$ & $\begin{array}{c}1(1.0-1.0) \\
0.009(0.007-0.011) \\
1.1(1.1-1.1) \\
6.3(3.2-9.4)\end{array}$ & $\begin{array}{c}3.3(3.3-3.3) \\
1.965(1.180-2.750) \\
0.7(0.6-0.8) \\
3.2(2.4-3.9)\end{array}$ & $\begin{array}{c}2.0(0.4-3.8) \\
1.500(0.140-2.690) \\
0.9(0.8-1.0) \\
2.8(2.6-2.9)\end{array}$ \\
\hline $\begin{array}{l}\text { Apgar score } \\
1^{\text {st }} \text { minute } \\
5^{\text {th }} \text { minute } \\
10^{\text {th }} \text { minute }\end{array}$ & & $\begin{array}{c}8.5(8-9) \\
10(10-10) \\
10(10-10)\end{array}$ & $\begin{array}{c}9(9-9) \\
10(10-10) \\
10(10-10)\end{array}$ & $\begin{array}{c}9(9-9) \\
10(10-10) \\
10(10-10)\end{array}$ \\
\hline $\begin{array}{l}\text { Birth somatome } \\
\text { (Z-scores) } \\
\text { Weight } \\
\text { Height } \\
\text { Head circumf. }\end{array}$ & & $\begin{array}{l}-0.7(-1.7-0.4) \\
-0.8(-2.1-0.5) \\
0.4(-1.1-1.9)\end{array}$ & $\begin{array}{c}0.2(-0.9-0.3) \\
-0.2(-1.2-0.7) \\
-0.2(-0.2--0.2)\end{array}$ & $\begin{array}{l}-0.6(-1.2--0.2) \\
-0.8(-1.4--0.1) \\
-0.2(-0.8-0.5)\end{array}$ \\
\hline $\begin{array}{l}\text { Cord blood } \\
\text { TRAb (27) } \\
\text { TSH (32) } \\
\text { fT4 (31) } \\
\text { fT3 (23) }\end{array}$ & $\begin{array}{l}\mathrm{U} / \mathrm{L} \\
\mathrm{mU} / \mathrm{L} \\
\mathrm{ng} / \mathrm{dL} \\
\mathrm{pg} / \mathrm{mL}\end{array}$ & $\begin{array}{c}40(40-40) \\
0.028(0.028-0.028) \\
1.2(1.2-1.2) \\
\text { NA }\end{array}$ & $\begin{array}{c}3.4(3.4-3.4) \\
133(133-133) \\
0.6(0.6-0.6) \\
1.9(1.9-1.9)\end{array}$ & $\begin{array}{c}0(0-1.7) \\
10.245(7.070-14.400) \\
1.1(0.9-1.2) \\
2.2(1.6-3.1)\end{array}$ \\
\hline Male & & $2(100 \%)$ & $1(33.3 \%)$ & $23(51.1 \%)$ \\
\hline Exclusive BF & & 1 & $2(100 \%)$ & $32(76.2 \%)$ \\
\hline $\begin{array}{l}\text { First neonatal t } \\
\text { TRAb (28) } \\
\text { TSH (45) } \\
\text { fT4 (43) } \\
\text { fT3 (26) }\end{array}$ & $\begin{array}{l}\mathrm{U} / \mathrm{L} \\
\mathrm{mU} / \mathrm{L} \\
\mathrm{ng} / \mathrm{dL} \\
\mathrm{pg} / \mathrm{mL}\end{array}$ & $\begin{array}{c}92.1(24.2-160.0) \\
0.006(0.005-0.007) \\
1.9(1.0-2.7) \\
6.1(2.9-9.3)\end{array}$ & $\begin{array}{c}0.7(0.7-0.7) \\
120.000(75.000-150.000) \\
1.0(0.6-1.4) \\
\text { NA }\end{array}$ & $\begin{array}{c}0.4(0.0-1.0) \\
3.340(1.840-5.000) \\
1.6(1.3-2.0) \\
5.1(4.3-6.0)\end{array}$ \\
\hline
\end{tabular}

Some values were under the detection nadir, therefore we considered them as zero. Measures of distribution: median and interquartile range. $₫: p<0.05$.

BF: breastfeeding; fT3: free triiodothyronine; fT4: free thyroxin; ${ }^{131}$ : radioactive iodine; NA: non-applicable/available; TRAb: thyrotropin receptor antibodies; TSH: thyrotropin/thyroid stimulating hormone; US: ultrasound; WG: weeks of gestation 
Table 4 - Characterization of the five mothers and respective neonates with dysthyroidism

\begin{tabular}{|c|c|c|c|c|c|}
\hline & $\begin{array}{c}1^{\text {st }} \text { trimester } \\
\text { treatment } \\
\text { TRAbs (U/L); TSH (mU/L) }\end{array}$ & $\begin{array}{c}2^{\text {nd }} \text { trimester } \\
\text { treatment } \\
\text { TRAbs }(\mathrm{U} / \mathrm{L}) ; \mathrm{TSH}(\mathrm{mU} / \mathrm{L})\end{array}$ & $\begin{array}{c}3^{\text {rd }} \text { trimester } \\
\text { treatment } \\
\text { TRAbs }(\mathrm{U} / \mathrm{L}) ; \mathrm{TSH}(\mathrm{mU} / \mathrm{L})\end{array}$ & $\begin{array}{c}\text { Blood cord } \\
\text { TRAbs (U/L); TSH (mU/L) }\end{array}$ & $\begin{array}{c}\text { First NN } \\
\text { TRAbs (U/L); TSH (mU/L) }\end{array}$ \\
\hline \multirow{2}{*}{ 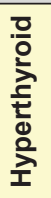 } & None; $29.4 ; 0.015$ & PTU; 22.6; 0.005 & MMI; 40; 0.011 & $40 ; 0.028$ & $24.2 ; 0.007$ \\
\hline & MMI; NA; NA & MMI; NA; 0.003 & None; NA; 0.007 & NA; NA & $160 ; 0.005$ \\
\hline \multirow{2}{*}{ 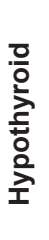 } & PTU; NA; NA & none; NA; NA & none; NA; NA & $N A ; N A$ & NA; 120.000 \\
\hline & MMI; NA; NA & MMI; 10.2; 0.000 & MMl; 3.3; 2.750 & $3.4 ; 133 \mathrm{mU} / \mathrm{L}$ & NA; 150.000 \\
\hline
\end{tabular}

LTX: levothyroxine; MMI: methimazole; NA: not available; NN: neonatal; PTU: propylthiouracil; TRAb: thyrotropin receptor antibodies; TSH: thyrotropin/thyroid stimulating hormone

in the first neonatal determination $(p=0.03)$, with higher levels of TRAb in the dysthyroid group as well.

\section{DISCUSSION}

In Portugal, there is not a systematic screening program of thyroid dysfunction in pregnant women. In a study published last year by Santos JA et al, only five centres out of the 24 responders $(20.80 \%)$ reported carrying out screening, mainly during the first pregnancy appointment. ${ }^{10}$ In our cohort, eight women were diagnosed less than a year before pregnancy. This makes it more difficult to achieve control of the disease. The lack of information led to a pregnant woman undergoing ${ }^{131} \mid$ therapy, compromising the control of the disease and culminating in a case of early neonatal hyperthyroidism, when different studies advise a safety window of 6 months between ${ }^{131}$ therapy and pregnancy. $6,7,18$

By maintaining focus on the mother's treatment, there was a decrease in the number of women on ATD during the third trimester, which is in line with the decrease of immune activity at the end of gestation. ${ }^{1}$ The use of methimazole (MMI) during the first trimester, an arguable point, as previously mentioned, represented almost $30 \%$ of mothers and one case presented with ultrasound abnormalities (fetal growth restriction) $)^{2,18}$

Out of those with ultrasound abnormalities, we highlight one case of thyroid hypertrophy, in which the thyroid function was always normal, which went against the reported sensitivity and specificity of $92 \%$ and $100 \%$, respectively, of the fetal thyroid ultrasound for the diagnosis of clinically relevant thyroid dysfunction. ${ }^{1}$

Although our Pediatric Endocrinology Unit published a protocol for evaluation of these offspring in 2014, there were nine cases without blood cord analysis afterwards, and in four cases it lacked all the required determinations (TSH, fT4, IT3 and TRAb). ${ }^{8}$ This emphasises the need for improving communication between pediatricians and obstetricians. The need for experienced multidisciplinary teams has been endorsed by various authors; for Léger, they should be comprised of adult and pediatric endocrinologists, obste- tricians and fetal radiologists. ${ }^{2,5}$

We confirmed the importance of TRAb levels in the blood cord, and in the first neonatal analysis. The absence of this determination in every pregnant woman may have influenced the fact that we did not find a significant difference between TRAb levels of mothers of euthyroid neonates and other mothers. We found a difference regarding fT 4 and fT3 during the second trimester, mirroring the control of GD, which is in agreement with the fact that neonatal complication rates are higher in women who remain hyperthyroid during the second half of pregnancy. ${ }^{4}$ There were no differences regarding measures at birth, Apgar index, breastfeeding at maternity discharge. In the study by Besançon $A$ et al, there was a positive correlation between TRAb titres in the cord blood and neonatal hyperthyroidism. The rapid rise of fT 4 between days 3 and 7 was also considered as a good predictor. ${ }^{20}$ For Banigé et al, TRAb in the cord blood indicated a higher rate of neonatal hyperthyroidism, as well as the rapid increase in $\mathrm{fT} 4 .^{3}$

The interest of measuring TSH in cord blood is questionable as there is evidence that the levels need to be interpreted considering perinatal factors such as a requirement for resuscitation and mode of delivery. ${ }^{20}$ For Samuels $S$ and colleagues, the utility of cord blood TSH and fT4 has not been established and is not recommended. ${ }^{7}$

Our incidence of neonatal hyperthyroidism fits the described rate of $1 \%$ to $5 \%$ of neonates born to mothers with GD. ${ }^{1}$

The two cases with hyperthyroidism had their clinical presentation in the first two weeks, which is in line with most of the literature, but it is worth mentioning that there have been described cases as late as 45 days of life. ${ }^{4}$ In these cases, recovery was fast with the instituted therapeutics, and therefore, it is essential to reinforce the need for a diligent transfer to an intensive care unit so they can start ATD and propanolol.9,22 Treatment duration is reported to be commonly 1 to 2 months, however our cases did it for 3 and 4 months. ${ }^{4}$ We had three cases of hypothyroidism, two of them transitory. In one of them, the mother was under 
treatment only during the first trimester, with PTU, while the other one took it throughout pregnancy. As such, we can infer that TRAb in these cases should have influenced more than the ATD, having here an inhibitory effect, as the duration of action of PTU is reported to be 12 to 24 hours. ${ }^{2,4}$

Our study has several limitations. Firstly, it has a retrospective nature. Nonetheless, the fact that laboratory tests during pregnancy differed from mother to mother, it exposed the lack of homogeneity in clinical practice. Besides that, the reference ranges vary between laboratories, and with the technique and machine in use, not to mention the absence of Portuguese studies establishing our population reference ranges. ${ }^{23}$ It would be good to conduct these kinds of studies in our country, as well as to establish a national protocol of evaluation of women in fertile age with GD. The size of our population was a handicap as it precluded the use of more advanced statistical packages to find the desired preclinical determinants of hyperthyroidism. In fact, there are few studies focusing on this subject, and these technical differences make comparisons difficult. 2,3,13,24,25

In the future, it would be interesting to evaluate in these patients the long-term repercussions of hyperthyroidism.

\section{CONCLUSION}

Dysthyroid neonates had mothers with significantly higher levels of fT4 and fT3, during the $2^{\text {nd }}$ trimester of pregnancy. TRAb levels are an important indicator that should

\section{REFERENCES}

1. Bucci I, Giuliani C, Napolitano G. Thyroid-stimulating hormone receptor antibodies in pregnancy: clinical relevance. Front Endocrinol. 2017;8:137.

2. Alexander EK, Pearce EN, Brent GA, Brown RS, Chen H, Dosiou C, et al. 2017 Guidelines of the American Thyroid Association for the Diagnosis and Management of Thyroid Disease During Pregnancy and the Postpartum. Thyroid. 2017;27:315-89.

3. Banigé M, Estellat C, Biran V, Desfrere L, Champion V, Benachi A, et al. Study of the factors leading to fetal and neonatal dysthyroidism in children of patients with Graves disease. J Endocr Soc. 2017;1:751-61.

4. van der Kaay DC, Wasserman JD, Palmert MR. Management of neonates born to mothers with Graves' disease. Pediatrics. 2016;137:pii e20151878.

5. Léger J. Management of fetal and neonatal Graves' disease. Horm Res Paediatr. 2017;87:1-6.

6. Zhang LH, Li JY, Tian Q, Liu S, Zhang H, Liu S, et al. Follow-up and evaluation of the pregnancy outcome in women of reproductive age with Graves' disease after 131lodine treatment. J Radiat Res. 2016;57:7028.

7. Samuels SL, Namoc SM, Bauer AJ. Neonatal thyrotoxicosis. Clin Perinatol. 2018;45:31-40.

8. Jerónimo M, Moinho R, Vicente IN, Oliveira A, Dias A, Mimoso G, et al. Hipertiroidismo neonatal transitório. Port Endocrinol Diabetes Metab. 2014;9:157-61.

9. Akangire G, Cuna A, Lachica C, Fischer R, Raman S, Sampath V. Neonatal Graves' disease with maternal hypothyroidism. AJP Rep. 2017;7:e181-4.

10. Santos JA, Martins NN, Clode N, Martins FN. Screenings during pregnancy - the national panorama. Acta Obstet Ginecol Port. 2017;11:174-80.

11. Direção-Geral da Saúde. Programa Nacional para a Vigilância da Gravidez de Baixo Risco - 16/09/2016. [consultado 2018 dez 20], Disponível em: https://www.dgs.pt/em-destaque/programa-nacionalpara-a-vigilancia-da-gravidez-de-baixo-risco.aspx.

12. Vilarinho L, Diogo L, Pinho e Costa L. Programa Nacional de Diagnóstico Precoce - Relatório 2015. Instituto Nacional de Saúde be accessed in cord blood and, if positive, during the first neonatal test.

\section{ACKNOWLEDGMENTS}

The authors want to thank all the medical doctors, pharmaceuticals and technicians who helped to access the files with the data.

\section{PROTECTION OF HUMANS AND ANIMALS}

The authors declare that the procedures were followed according to the regulations established by the Clinical Research and Ethics Committee and to the Helsinki Declaration of the World Medical Association.

\section{DATA CONFIDENTIALITY}

The authors declare having followed the protocols in use at their working center regarding patients' data publication.

\section{COMPETING INTERESTS}

The authors have declared that no competing interests exist.

\section{FUNDING SOURCES}

This work was done as part of the clinical research of the Unit, without external financial support.

Doutor Ricardo Jorge. [consultado 2018 nov 15]. Disponível em: http:// www.diagnosticoprecoce.org/divulgacao.htm.

13. Sociedade de Endocrinologia e Diabetologia Pediátrica. Recém-nascido filho de mãe com doença tiroideia - 2019. [consultado 2019 jan 20]. Disponível em: http://www.spp.pt/UserFiles/file/Relatorios\%20seccoes/ Protocolo_Patologia.da.tiroide_SEDP.pdf.

14. Banigé $\bar{M}$, Polak $M$, Luton $D$; Research Group for Perinatal Dysthyroidism (RGPD) Study Group. Prediction of neonatal hyperthyroidism. J Pediatr. 2018;197:249-54.e1.

15. Adeli K, Higgins V, Trajcevski K, White-Al Habeeb N. The Canadian laboratory initiative on pediatric reference intervals: a CALIPER white paper. Crit Rev Clin Lab Sci. 2017;54:358-413.

16. Bocos-Terraz JP, Izquierdo-Álvarez S, Bancalero-Flores JL, ÁlvarezLahuerta R, Aznar-Sauca A, Real-López E, et al. Thyroid hormones according to gestational age in pregnant Spanish women. BMC Res Notes. 2009;2:237.

17. Mehari A, Challa F, Gebreyesus G, Alemayehu D, Seifu D. Establishment of reference intervals of thyroid function tests from cord blood of neonates in two selected hospitals, Addis Ababa, Ethiopia. BMC Pediatr. 2016;16:118.

18. Kahaly GJ, Bartalena L, Hegedüs L, Leenhardt L, Poppe K, Pearce SH. 2018 European Thyroid Association Guideline for the Management of Graves' Hyperthyroidism. Eur Thyroid J. 2018;7:167-86.

19. Fernandez Rodriguez B, Perez Diaz AJ. Evaluation of a follow up protocol of infants born to mothers with antithyroid antibodies during pregnancy. J Matern Fetal Neonatal Med. 2018;31:312-9.

20. Besançon A, Beltrand J, Le Gac I, Luton D, Polak M. Management of neonates born to women with Graves' disease: a cohort study. Eur J Endocrinol. 2014;170:855-62.

21. Gupta A, Srivastava S, Bhatnagar A. Cord blood thyroid stimulating hormone level--interpretation in light of perinatal factors. Indian Pediatr. 2014;51:32-6.

22. Joshi K, Zacharin M. Hyperthyroidism in an infant of a mother with autoimmune hypothyroidism with positive TSH receptor antibodies. J Pediatr Endocrinol Metab. 2018;31:577-80.

23. Ramos T, Mariano C, Bourbon M. Analysis of thyroid status in a 
Portuguese adult population. Boletim Epidemiológico Observações. 2017;3:13-6.

24. van Dijk MM, Smits IH, Fliers E, Bisschop $\mathrm{PH}$. Maternal thyrotropin receptor antibody concentration and the risk of fetal and neonatal thyrotoxicosis: a systematic review. Thyroid. 2018;28:257-64. doi:
25. Barth JH, Luvai A, Jassam N, Mbagaya W, Kilpatrick ES, Narayanan $D$, et al. Comparison of method-related reference intervals for thyroid hormones: studies from a prospective reference population and a literature review. Ann Clin Biochem. 2018;55:107-12. 